\author{
ЦИФРОВА ЕКОНОМІКА: \\ ДЕРЖАВНЕ РЕГУЛЮВАННЯ ТА СТРАТЕГІЯ РОЗВИТКУ \\ DIGITAL ECONOMY: \\ GOVERNMENT REGULATION AND DEVELOPMENT STRATEGY
}

УДК 330.47:338.24

https://doi.org/10.32843/bses.53-34

\section{Білоскурський P.P.}

д.е.н., доцент,

декан економічного фракультету

Чернівецький національний університет імені Юрія Федьковича

\section{Biloskurskyy Ruslan \\ Yuriy Fedkovych Chernivtsi National University}

\begin{abstract}
у статті обірунтовано стратегію розвитку цифрової економіки в Україні з виділенням механізмів ії державного регулювання. Розглянуто базовий та прискорений сценарії розвитку цифрової економіки в Україні. Запропоновано підхід до розроблення комплексної стратегії цифррового розвитку України, яка конкретизується у часовому розрізі досягнення мети. Короткострокова мета полягає у вирішенні актуальних проблем подолання цифрової нерівності, забезпеченні швидкісного доступу до мережі Інтернет та цифррової грамотності для всіх. Середньостроковою метою $є$ забезпечення відповідного економічного зростання на основі цифрових технологій, прискорений розвиток промисловості на основі концепції Індустрія 4.0, формування комплексної цифрровоі інфрраструктури. Довгостроковою метою $\epsilon$ формування розвиненої соціально орієнтованої та безпечної цифрової екосистеми суспільства зі збалансованим інституціональним середовищем. Досліджено нормативно-правові, адміністративні, фрінансові, економічні та інформаційні механізми державного регулювання цифрової економіки. Ключові слова: цифрова економіка, стратегія розвитку, механізми державного регулювання, Індустрія 4.0, цифровізація.
\end{abstract}

В статье обоснована стратегия развития цисровой экономики в Украине с выде- лением механизмов ее государственного регулирования. Рассмотрены базовый и ускоренный сценарии развития цифровой экономики в Украине. Предложен подход к разработке комплексной стратегии цифррового развития Украины, которая конкретизируется во временном разрезе достижения цели. Краткосрочная чель заключается в решении актуальных проблем преодоления цифрового неравенства, обеспечении скоростного доступа к сети Интернет $u$ цифровой грамотности для всех. Среднесрочной челью является обеспечение соответствующего экономического роста на основе цифровых технологий, ускоренное развитие промышленности на основе концепции Индустрия 4.0, фрормирование комплексной цифрровой инфрраструктуры. Долгосрочной челью является формирование развитой социально ориентированной и безопасной циорровой экосистемы общества со сбалансированной институциональной средой. Исследованы нормативно-правовые, административные, финансовые, экономические и информационные механизмы государственного регулирования цифровой экономики.

Ключевые слова: цифрровая экономика, стратегия развития, механизмы государственного регулирования, Индустрия 4.0, циорровизация.

The strategy of digital economy development in Ukraine with the allocation of mechanisms of its state regulation is considered in the article. The basic and accelerated scenarios of digital economy development in Ukraine are considered. An approach to the development of a comprehensive strategy for digital development of Ukraine is proposed, which is specified in the time frame of achieving the goal. The primary goals are the urgent problems of overcoming digital inequality between cities and villages. To do this, it is necessary to create access to broadband high-speed Internet for residents of villages and remote areas, to ensure full coverage of the fourth generation $4 \mathrm{G}$ mobile radio standard by all mobile operators, to introduce the concept of digital workplaces, to continuously upgrade computer equipment in educational institutions. Create institutions for teaching digital literacy to the elderly. Secondary goals of digital economy development in Ukraine: ensuring sustainable economic development of 5-7\% of GDP annually on the basis of innovative sectors of digital economy, modernization and implementation of technologies of the Industry 4.0 concept in industrial enterprises, development of agriculture based on precision agriculture, transition to decentralized registers using blockchain technologies, expanding access to public data, digitalization of the entire life support infrastructure: medicine, transport, education, environmental monitoring, tourism, implementation of e-government elements. The higher goals of the comprehensive strategy of the digital economy in Ukraine are to form a new ecosystem of society that operates in an innovative knowledge economy, artificial intelligence, continuous computer data processing, which are constantly measured by electronic sensors and sensors and processed in real time by machine algorithms optimal solutions in global systems. Social justice, protection of the right to privacy, cyber security and environmental sustainability are important components of the long-term goal. The normative-legal, administrative, financial, and economic and information mechanisms of state regulation of the digital economy are studied.

Key words: digital economy, development strategy, mechanisms of state regulation, Industry 4.0, digitalization.

Постановка проблеми. Цисровізація разом із глобалізацією $є$ найбільш значущим трендом сучасного етапу розвитку людства. На перший погляд, вона полягає у збільшенні різноманітних електронно-цифрових пристроїв, поширенні комп'ютерно-інформаційних технологій, автоматизації виробничих процесів. Проте такий погляд $€$ занадто лінійним, спрощеним і не відображає глибини трансформацій, що зумовлені цифровими технологіями. Інформатизація та цифровізація задають новий порядок взаємодії держави, економіки та суспільства, що базується на глобальному проникненню «цифри» в усі сфери життєдіяльності людини, зумовлюючи необхідність наукового дослідження феномена цифрової економіки. 
Такі нові цифрові технології, як блокчейн, розподілені реєстри та криптовалюти; штучний інтелект, машинне навчання та нейронні мережі; Інтернет речей; віртуальна та доповнена реальність; робототехніка; адитивне виробництво та багатомірний друк; хмарні технології зберігання та оброблення великих даних, крім абсолютно нових можливостей, породжують низку нових ризиків, а саме звільнення та безробіття великої кількості працівників традиційних сорер економіки, соціальне розшарування; фрінансування тероризму та відмивання коштів; загрози втручання кібернетичних систем в особисте життя; шахрайські дії з криптовалютами та безготівковими рахунками, накопичення електронного сміття, негативний вплив випромінювання електронно-цифрових пристроїв на здоров'я людини. Можливості та ризики цифрової економіки зумовлюють необхідність регулювання та стратегії розвитку на рівні держави, що підкреслює актуальність нашого дослідження.

Аналіз останніх досліджень і публікацій. Однією з перших та найбільш цитованих наукових публікацій з проблем цифрової економіки українською мовою є стаття С.В. Коляденко [1], у якій вивчаються основні етапи цифрової економіки як нової категорії в економічній науці. Автор визначає цифрову економіку як економіку, що базується на цифрових комп'ютерних технологіях, яку також іноді називають інтернет-економікою, новою економікою або веб-економікою. Сучасний стан, тренди та перспективи, ризики та загрози цифрової економіки в Україні детально досліджували такі вітчизняні науковці, як Н.М. Краус, О.П. Голобородько, К.М. Краус [2], М.В. Руденко [3], В.В. Апалькова [4], П.Р. Пуцентейло, О.О. Гуменюк [5], Л.О. Матвейчук [6], К.Й. Пугачевська, К.С. Пугачевська [7], О.І. Піжук [8].

Постановка завдання. Метою дослідження $€$ наукове обґрунтування стратегії розвитку цифрової економіки в Україні з виділенням механізмів її державного регулювання.

Виклад основного матеріалу дослідження. Існує два сценарії розвитку циоррової економіки в Україні, а саме базовий (інерційний) та прискорений. Базовий сценарій розвитку передбачає, що процеси цифровізації в країні будуть відбуватися й надалі без активного сприяння та регулювання держави, переважно за рахунок приватних інвестицій та ініціатив бізнесу з подальшою повільною та несистемною цифровою трансформацією державного та комунального секторів. Такий варіант посилить цифровий розрив між мешканцями великих міст та сіл, провокуватиме виїзд за кордон кращих спеціалістів, збільшить соціальну несправедливість.

Прискорений сценарій цифррового розвитку, згідно з Концепцією розвитку цифрової економіки та суспільства України на 2018-2020 роки, передбачає [9]:

- усунення законодавчих, інституційних, фріскальних та інших перешкод, які заважають розвитку циоррової економіки;
- впровадження стимулів та мотивацій для заохочення бізнесу та індустрій економіки загалом до циорровізації;

- створення попиту та фрормування потреб серед громадян до цифровізації, насамперед, через впровадження державою масштабних проєктів цифрових трансорормацій, зокрема на базі сучасних моделей державно-приватного партнерства;

- створення та розвиток циоррових інфрраструктур як основи використання переваг цифрового світу у повсякденному житті та платформи для досягнення ефективності економіки загалом;

- розвиток та поглиблення цифрових компетенцій громадян для забезпечення їх готовності до використання цифрових можливостей, а також подолання супутніх ризиків;

- розвиток цифрового підприємництва, створення відповідних (зокрема, аналогових) інфрраструктур для підтримки та розвитку інноваційної діяльності, впровадження механізмів фрондування, стимулювання та підтримки.

Загалом важко не погодитися з В.В. Апальковою в тому, що «Україна має непогані шанси на скорочення «електронних перешкод», якщо тільки держава почне будувати регуляторну політику відповідно до загальносвітових практик і не створюватиме штучних перешкод для розвитку бізнесу» [4, с. 17]. Н.М. Краус, О.П. Голобородько, К.М. Краус також підкреслюють роль держави й вказують на те, що «активне розгортання високошвидкісних мереж залежить від стимулювання з боку держави: зосередивши увагу на фрормуванні оптимальних ринкових умов, ми маємо створити стимули для могутньої експансії на даному ринку приватного капіталу» [2]. «Для успішного розвитку цифрової економіки в Україні потрібна ефективна державна політика її стимулювання», - робить висновок у праці [8, с. 82] О.І. Піжук. Авторський колектив аналітичного центру «Український інститут майбутнього» визначає, що для розвитку інноваційної економіки, цифрової модернізації та трансформації держава повинна взяти на себе відразу декілька ролей, а саме лідера та експериментатора, регулятора й захисника, популяризатора [10].

Законодавчі засади цифрової економіки, цифровізації та цифрового суспільства в Україні ініціюються та напрацьовуються за активної участі Комітету з питань цифрової трансформації Верховної Ради України. Так, Комітет підготував Проєкти Законів України, прийняття яких сприятиме прискореному сценарію цифррового розвитку, а саме Проєкт Закону про внесення змін до деяких законів України щодо доступу до інорраструктури об'єктів будівництва, транспорту, електроенергетики, Проєкт Закону про внесення змін до Закону України «Про захист інфрормації в інфрормаційно-телекомунікаційних системах» (щодо підтвердження відповідності інформаційної системи вимогам із захисту 
інформації), Проєкт Закону про публічні електронні реєстри, Проєкт Закону про хмарні послуги, Проєкт Закону про електронні комунікації [11].

Надзвичайно важливим рішенням для становлення та розбудови інституціонального середовища цифрової економіки в Україні стало створення у вересні 2019 року окремого Міністерства цифррової транссоормації України, яке покликане забезпечити орормування та реалізацію державної політики у цифровій економіці та супутніх сфрерах. На сайті Міністерства та Комітету цифрової трансформації України встановлено такі цілі Міністерства до 2024 року [12]:

- 100\% публічних послуг доступні громадянам та бізнесу онлайн;

- 95\% транспортної інфрраструктури, населених пунктів та їхні соціальні об'єкти мають доступ до високошвидкісного Інтернету;

- 6 млн. українців залучені до програми розвитку цифрових навичок;

- 10\% становить частка IT у ВВП країни.

При цьому Комітет з питань цисррової трансформації Верховної Ради України декларує своїми цілями законодавчо забезпечити цілі Міністерства, що засвідчує узгодження планів двох важливих державних інституцій, а саме законодавчої та виконавчої.

М.В. Руденко справедливо виділяє позитивні есректи від цисрровізації економіки на трьох рівнях $[3$, c. 64]:

- цифрова трансформація економіки державного управління відбувається переважно 3 використанням електронних каналів взаємодії для зниження трансакційних витрат, оскільки звичайні відносини замінюються електронним аналогом; ці зміни повинні супроводжуватися трансорормацією класичних інститутів для підвищення рівня довіри до електронної сфери;

- цифрровізація реального сектору економіки зміцнить конкурентні позиції вітчизняних підприємств за рахунок підвищення продуктивності праці, ефрективності управління, прискореної автоматизації виробничих процесів, безпечності виробництва та зробить галузі вітчизняної економіки більш привабливими для інвестицій;

- переваги від цифрровізації для суспільства очевидні, оскільки користувачем цифрових продуктів та послуг $є$ саме населення, яке має змогу отримувати швидкісний доступ до Інтернету, інформації та бази знань, що робить наше життя більш комфортним та зручним, тобто таким, що відповідає реаліям сьогодення.

На рис. 1 відображено авторський підхід до розроблення комплексної стратегії цифрового розвитку України, яка конкретизується у часовому розрізі досягнення мети. Первинними цілями $€$ нагальні проблеми подолання цифрової нерівності між містами та селами. Для цього необхідно створити доступ до широкосмугового швидкісного Інтернету для мешканців сіл та віддалених територій, забезпечити повне покриття території України стандартом четвертого покоління мобільного радіозв'язку 4G усіма мобільними операторами, впроваджувати концепцію цисррових робочих місць, здійснювати неперервну модернізацію комп'ютерного обладнання в освітніх закладах, створювати інституції для навчання цифровій грамотності людей похилого віку.

Вторинними цілями розвитку цисррової економіки в Україні є забезпечення стійкого економічного розвитку в розмірі 5-7\% ВВП щорічно на основі

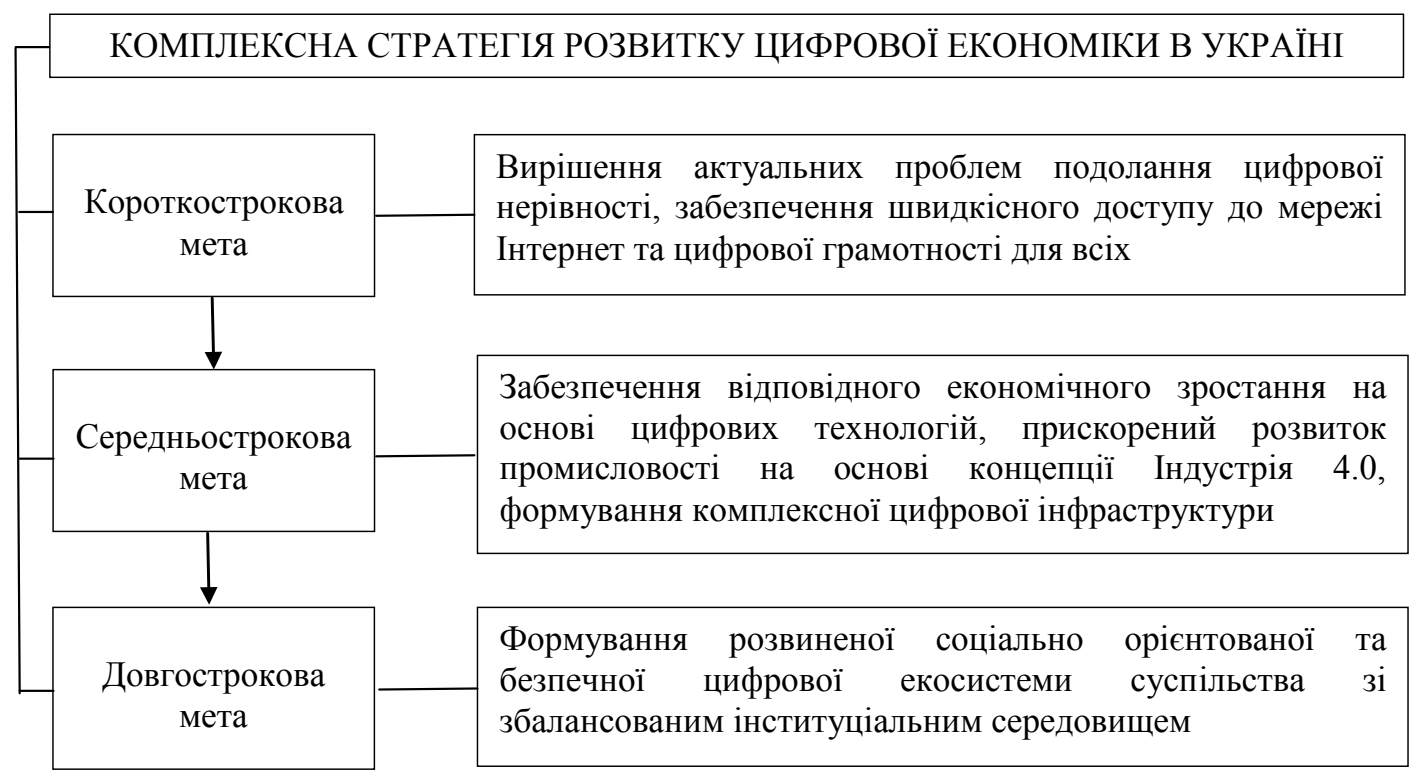

Рис. 1. Комплексна стратегія цифрового розвитку України

в розрізі різнострокової перспективи досягнення мети 
інноваційних секторів цифррової економіки, модернізація та впровадження технологій концепції Індустрія 4.0 в діяльність промислових підприємств, розвиток сільського господарства на базі точного землеробства, перехід на децентралізовані реєстри, що використовують технології блокчейн, розширення доступу до публічних даних, цифрровізація усієї інфраструктури життєзабезпечення, а саме таких сорер, як медицина, транспорт, освіта, природоохоронний моніторинг, туризм, впровадження елементів електронного врядування.

Вищі цілі комплексної стратегії цифрової економіки в Україні полягають у фрормуванні нової екосистеми суспільства, що функціонує в умовах інноваційної економіки знань, штучного інтелекту, неперервної комп'ютерної обробки даних, які постійно вимірюються електронними сенсорами й датчиками та в режимі реального часу опрацьовуються машинними алгоритмами для прийняття оптимальних рішень в умовах глобальних систем. Важливими складовими частинами довгострокової мети є соціальна справедливість, захист прав на невтручання в особисте життя громадян, кібернетична безпека та екологічна сталість.

К.Й. Пугачевська та К.С. Пугачевська визначають передумови розвитку цифрової економіки в Україні, виділяючи кілька аспектів: «система освіти має високий потенціал для підготовки фрахівців цисрової економіки; $є$ оригінальні організаційно-технологічні рішення зі створення ефективної інфрраструктури цифрової економіки; інтеграція і розвиток конкретних кейсів на базі сучасних принципів цифрової економіки створять синергетичний еорект, що приведе до загального зростання економіки» [7, с. 44].

Реалізація комплексної стратегії цисррового розвитку України є можливою через призму раціонального застосування механізмів державного регулювання, які можна типізувати такими класами.

1) Нормативно-правові механізми - це система юридичних засобів, способів і методів впливу на суспільні відносини, яка дає змогу втілювати в життя встановлені правила та норми поведінки. Важливо, щоби вітчизняне законодавство було гармонізоване з міжнародним, зокрема законодавством ЄC.

2) Адміністративні механізми - це встановлення норм, регламентів, дозвільної системи під час впровадження телекомунікаційних та радіоелектронних пристроїв та апаратури; визначення та встановлення системи штрафрів та покарань за втручання та пошкодження як фрізичних пристроїв, так і систем оброблення інорормації.

3) Фінансові механізми - це визначення обсягів бюджетного фрінансування циоррових транссрормацій, субсидування кредитів та надання грантів, залучення приватних інвестицій на основі взаємовигідного приватно-державного партнерства, фрормування справедливої системи оподаткування.
4) Економічні механізми - це фрормування структурних змін в економіці країни в контексті забезпечення цифрровізації, зростання ВВП та сталий соціально-економічний розвиток країни, регіонів, населених пунктів, сприяння міжнародному співробітництву, розвиток цифрових кластерів, підтримка стартапів, забезпечення еколого-економічної збалансованості.

5) Інорормаційні механізми - це сприяння фрормуванню нової цисррової культури населення, організація просвітницької роботи серед людей старшого віку, прогнозування потреби в спеціалістах цисрової економіки, створення нових освітніх та освітньонаукових програм у закладах вищої освіти для задоволення потреб цифрової економіки, фрормування кваліфікаційних вимог до їх вмінь та компетенцій, надання консультаційних інорормаційних послуг.

Системний аналіз механізмів державного регулювання та практики їх застосування детально розглядався нами у дослідженні [13].

Висновки з проведеного дослідження. Циоррова економіка таїї динаміка, технології, принципи, характеристики докорінно змінюють глобальну та національну економічну систему. Держава у цьому процесі повинна бути гарантом розроблення візії та впровадження стратегії розвитку цисррової економіки в Україні, довгостроковою метою якої є фрормування розвиненої соціально орієнтованої та безпечної цифрової екосистеми суспільства зі збалансованим інституціальним середовищем.

\section{БІБЛІОГРАФІЧНИЙ СПИСОК:}

1. Коляденко С.В. Цифрова економіка: передумови та етапи становлення в Україні. Економіка. Фінанси. Менеджмент: актуальні питання науки $і$ практики. 2016. № 6. С. 105-112.

2. Краус Н.М., Голобородько О.П., Краус К.М. Цисрова економіка: тренди та перспективи авангардного характеру розвитку. Ефективна економіка. 2018. № 1. URL: http://www.economy.nayka.com. ua/?op=1\&z=6047 (дата звернення: 04.06.2020).

3. Руденко М.В. Цифровізація економіки: нові можливості та перспективи. Економіка та держава. 2018. № 11. С. 61-65.

4. Апалькова В.В. Концепція розвитку цифрової економіки в Євросоюзі та перспективи України. Вісник Дніпропетровського університету. Серія : Менеджмент інновацій. 2015. № 4. С. 9-18.

5. Пуцентейло П.Р., Гуменюк О.О. Цисррова економіка як новітній вектор реконструкції традиційної економіки. Інноваційна економіка. 2018. № 5-6. С. 131-143.

6. Матвейчук Л.О. Цифррова економіка: теоретичні аспекти. Вісник Запорізького національного університету. Економічні науки. 2018. № 4 (40). C. 116-127.

7. Пугачевська К.Й., Пугачевська К.С. Цифровізація економіки як фрактор підвищення конкурентоспроможності країни. Інфраструктура ринку. 2018. Вип. 25. С. 39-45. 
8. Піжук О.І. Цифррова трансформація економіки як основа фрормування ії конкурентоспроможності. Східна Європа: економіка, бізнес та управління. 2018. Вип. 6 (17). С. 79-83.

9. Про схвалення Концепції розвитку цифрової економіки та суспільства України на 2018-2020 роки та затвердження плану заходів щодо їі реалізації : Розпорядження Кабінету Міністрів України від 17 січня 2018 року від № 67-p. URL: https://zakon. rada.gov.ua/laws/show/67-2018-\%D1\%80 (дата звернення: 04.06.2020).

10. Україна 2030Е - країна з розвинутою цифровою економікою. URL: https://strategy.uifuture.org/kraina-zrozvinutoyu-cifrovoyu-ekonomikoyu.html\#6-2-6 (дата звернення: 04.06.2020).

11. Офіційний веб-портал Верховної Ради України. URL: http://w1.c1.rada.gov.ua/pls/zweb2/webproc6_ current_main?id=\&pid069=248 (дата звернення: 04.06.2020).

12. Сайт Міністерства та Комітету цифрової трансорормації України. URL: https://thedigital.gov.ua/ ministry (дата звернення: 04.06.2020).

13. Білоскурський Р.P. Механізми державного регулювання в системі еколого-економічного розвитку України. Український журнал прикладної економіки. 2017. Т. 2. Вип. 1. С. 14-27.

\section{REFERENCES:}

1. Koliadenko S.V. (2016) Tsyfrova ekonomika: peredumovy ta etapy stanovlennia v Ukraini [Digital economy: preconditions and stages of formation in Ukraine]. Ekonomika. Finansy. Menedzhment: aktualni pytannia nauky i praktyky, no. 6, pp. 105-112.

2. Kraus N.M., Holoborodko O.P., Kraus K.M. (2018) Tsyfrova ekonomika: trendy ta perspektyvy avanhardnoho kharakteru rozvytku [Digital economy: trends and prospects of avant-garde development]. Efektyvna ekonomika, no. 1. URL: http://www.economy.nayka.com.ua/ ?op=1\&z=6047 (accessed: 4 June 2020).

3. Rudenko M.V. (2018) Tsyfrovizatsiia ekonomiky: novi mozhlyvosti ta perspektyvy [Digitization of the economy: new opportunities and prospects]. Ekonomika ta derzhava, no. 11, pp. 61-65.

4. Apalkova V.V. (2015) Kontseptsiia rozvytku tsyfrovoi ekonomiky $v$ Yevrosoiuzi ta perspektyvy Ukrainy [The concept of digital economy development in the
European Union and prospects of Ukraine]. Visnyk Dnipropetrovskoho universytetu. Seriia: Menedzhment innovatsii, no. 4, pp. 9-18.

5. Putsenteilo P.R., Humeniuk O.O. (2018) Tsyfrova ekonomika yak novitnii vektor rekonstruktsii tradytsiinoi ekonomiky [Digital economy as the newest vector of reconstruction of traditional economy]. Innovatsiina ekonomika, no. 5-6, pp. 131-143.

6. Matveichuk L.O. (2018) Tsyfrova ekonomika: teoretychni aspekty [Digital economy: theoretical aspects]. Visnyk Zaporizkoho natsionalnoho universytetu. Ekonomichni nauky, no. 4 (40), pp. 116-127.

7. Puhachevska K.I., Puhachevska K.S. (2018) Tsyfrovizatsiia ekonomiky yak faktor pidvyshchennia konkurentospromozhnosti krainy [Digitalization of the economy as a factor in increasing the country's competitiveness]. Infrastruktura rynku, no. 25, pp. 39-45.

8. Pizhuk O.I. (2018) Tsyfrova transformatsiia ekonomiky yak osnova formuvannia yii konkurentospromozhnosti [Digital transformation of the economy as a basis for the formation of its competitiveness]. Skhidna Yevropa: ekonomika, biznes ta upravlinnia, no. 6 (17), pp. 79-83.

9. Pro skhvalennia Kontseptsii rozvytku tsyfrovoi ekonomiky ta suspilstva Ukrainy na 2018-2020 roky ta zatverdzhennia planu zakhodiv shchodo yii realizatsii : Rozporiadzhennia Kabinetu Ministriv Ukrainy vid 17 sichnia 2018 roku № 67-r. URL: https://zakon.rada.gov.ua/laws/ show/67-2018-\%D1\%80 (accessed: 4 June 2020).

10. Ukraina 2030E - kraina z rozvynutoiu tsyfrovoiu ekonomikoiu [Ukraine 2030E is a country with a developed digital economy]. URL: https://strategy.uifuture.org/kraina-z-rozvinutoyu-cifrovoyu-ekonomikoyu. html\#6-2-6 (accessed: 4 June 2020).

11. Official web portal of the Verkhovna Rada of Ukraine. URL: http://w1.c1.rada.gov.ua/pls/zweb2/webproc6_current_main?id=\&pid069=248 (accessed: 4 June 2020).

12. Website of the Ministry and the Committee for Digital Transformation of Ukraine. URL: https://thedigital.gov.ua/ministry (accessed: 4 June 2020).

13. Biloskurskyy R.R. (2017) Mekhanizmy derzhavnoho rehuliuvannia $v$ systemi ekoloho-ekonomichnoho rozvytku Ukrainy [Mechanisms of state regulation in the system of ecological and economic development of Ukraine]. Ukrainskyi zhurnal prykladnoi ekonomiky, no. 2.1, pp. 14-27. 